\title{
Izprana tla v Sloveniji: pedološke lastnosti, prostorska razporeditev in klasifikacija
}

\author{
Rok TURNIŠKI ${ }^{1}$, Helena GRČMAN ${ }^{2}$
}

Received November 17, 2017; accepted Februar 11, 2018.

Delo je prispelo 17. novembra 2017, sprejeto 11. februarja 2018.

\section{IZVLEČEK}

Eluvialno-iluvialni procesi so ključni pri pedogenezi. Po podatkih pedološke karte Slovenije 1: 25.000 izprana tla pokrivajo $2,3 \%$ površine. Pojavljajo se na različnih matičnih podlagah, večinoma na uravnanem površju, kjer so zavarovana pred erozijskimi in koluvialnimi procesi. Namen naše raziskave je ovrednotenje njihovih morfoloških, fizikalnih in kemičnih lastnosti, prostorske razporeditve in vpliva tlotvornih dejavnikov, predvsem matične podlage, na njihov nastanek. Pedološke lastnosti smo ovrednostili na podlagi analitskih in opisnih podatkov 49 izpranih tal iz pedološke baze Talnega informacijskega sistema Slovenije. Očitne znake procesov izpiranja smo prepoznali $\mathrm{v}$ večini profilov izpranih tal. Eluvialni horizont je imel $\mathrm{v}$ primerjavi $\mathrm{z}$ iluvialnim običajno nižji $\mathrm{pH}$, v povprečju za 0,2 enote, svetlejšo barvo, manjšo vsebnost bazičnih kationov (v povprečju za 16,6 \%) in manjšo kationsko izmenjalno kapaciteto (v povprečju za $5,5 \mathrm{mmol}_{\mathrm{c}}$ $100 \mathrm{~g}^{-1}$ tal). Povprečno razmerje $\mathrm{v}$ vsebnosti gline med iluvialnim in eluvialnim horizontom je 1,63. $75 \%$ izpranih tal ima razmerje v vsebnosti gline nad 1,38. Na podlagi kriterijev WRB klasifikacije smo argični horizont določili 40 profilom, medtem ko ostalih 9 ni ustrezalo kriterijem ali pa ni bilo na voljo podatkov za klasifikacijo. Podroben pregled WRB kriterijev (kationska izmenjalna kapaciteta preračunana na vsebnost gline in delež bazičnih kationov $\mathrm{v}_{\mathrm{t}}$ horizontih) je pokazal, da se pojavljata dve referenčni skupini: luvisoli in alisoli. Proti pričakovanju in dosedanjim znanstvenim objavam nismo evidentirali akrisolov $\mathrm{v}$ bazi pedoloških profilov Pedološke karte Slovenije.

Ključne besede: tla; eluvialno-iluvialno procesi; pedološke lastnosti; klasifikacija tal

\section{ABSTRACT \\ LEACHED SOILS IN SLOVENIA: PEDOLOGICAL PROPERTIES, SPATIAL DISTRIBUTION AND CLASSIFICATION}

Eluvial-illuvial processes plays key role in pedogenesis, especially in the development of leached soils. As reported in Slovenian soil map 1:25.000 leached soils cover 2,3\% of Slovenian territory. They occur on different parent materials, mostly on flat relief preserved from erosion and colluvial processes. The aim of our study is the evaluation of their morpohological, physical and chemical properties, spatial distribution and dependency on soil forming factors, especially on parent material. Pedological properties are demonstrated according to analytical and descriptive data of 49 leached soils from the pedological base of Soil Information System of Slovenia. Obvious leaching processes are clearly recognized in almost all profiles of leached soils. Eluvial horizon in comparison to illuvial horizon has lower $\mathrm{pH}$ value, which is in average 4,4 and 4,6 for $\mathrm{E}$ and Bt horizon respectively, brighter color, lower base saturation (in average for 16,6\%) and lower CEC (in average for 5,5 $\mathrm{mmol}_{\mathrm{c}} 100 \mathrm{~g}^{-1}$ soil). On average ratio of clay content between illuvial and eluvial horizon is 1,63 . In the $75 \%$ of all studied leached soils this ratio is above 1,38 . After evaluation, according to WRB classification, an argic horizon is identified only in 40 soil profiles, while other 9 profiles do not match criteria of sufficient textural differentiation or there is not enough data to classify them. Detailed overview of the WRB criteria for argic horizons (cation exchange capacity of clay fraction and base saturation in argic horizons) reveals that Luvisols and Alisols are the most widespread groups in Slovenia among leached soil. Against expectations based on different references, we do not determined Acrisols within Soil Map Database.

Key words: soil; eluvial-illuvial processes; pedological properties; soil classification

\footnotetext{
1 M.Sc., Univerza $v$ Ljubljani, Biotehniška fakulteta, Oddelek za agronomijo, Jamnikarjeva 101, SI-1111 Ljubljana, Slovenija, e-mail: rok.turniski@bf.uni-lj.si

2 Prof. Ph.D., Univerza v Ljubljani, Biotehniška fakulteta, Oddelek za agronomijo, Jamnikarjeva 101, SI-1111 Ljubljana, Slovenija, e-mail: helena.grcman@bf.uni-lj.si
} 


\section{UVOD}

Eluvialno-iluvialni procesi imajo pomembno vlogo pri razvoju tal, predvsem $\mathrm{v}$ okoljih $\mathrm{z}$ izrazitimi procesi izpiranja (Vidic in Lobnik, 1997; Quénard in sod., 2011), ki se odvijajo na območjih z zadostno letno količino efektivnih padavin. O njihovem pojavljanju poročajo iz Kanade (Lavkulich in Arocena, 2011), ZDA (Bockheim in Hartemink, 2013), Evrope (Kühn in sod., 2006; Quénard in sod., 2011; Costantini in sod., 2013; Carballas in sod., 2016, Fedoroff, 1997) in drugje. Tal, za katera so eluvialno-iluvialni procesi ključni, je po oceni IUUS Working group WRB (2015) na svetu približno 25,7 milijonov $\mathrm{km}^{2}$. Med najbolj razširjenimi referenčnimi talnimi skupinami so akrisoli, sledijo luvisoli, lixisoli, retisoli in alisoli. V Evropi so najbolj razširjeni retisoli in luvisoli (21\%), v manj kot odstotku se pojavljajo akrisoli in alisoli (Soil Atlas of Europe, 2005). Tla opredelimo kot izprana, če imajo izraženo teksturno diferenciacijo med horizonti ob sočasni prisotnosti diagnostičnega eluvialnega (E) horizonta. Iz eluvialnega horizonta se poleg glinenih mineralov izpirajo tudi bazični kationi, topna organska snov ter druge komponente tal (Blume in sod., 2016). Teksturno razliko $\mathrm{v}$ talnem profilu je običajno mogoče zaznati $\mathrm{s}$ prstnim poskusom. Kot znak premeščanja gline se $\mathrm{v} \mathrm{B}_{\mathrm{t}}$ horizontih na stenah por in strukturnih agregatov pojavljajo glinene prevleke. Izraz »izpiranje« (ang.: leaching) se v tuji literaturi uporablja za poimenovanje izpiranja $\mathrm{v}$ talni raztopini raztopljenih snovi iz profila $\mathrm{v}$ podtalje (Shaetzl in Anderson, 2005). Pri nas je uporaba izraza vezana tako na proces izpiranja iz tal $\mathrm{v}$ podtalje kot tudi na proces premeščanja snovi znotraj tal (iz zgornjih plasti v globlje dele tal). V pedološki literaturi za proces premeščanja gline po profilu navzdol običajno uporabljajo francoski izraz lessivage, ki je prisoten tudi v starejši domači literaturi (Stritar 1972, 1984, 1990; Sušin, 1964), kjer izprana tla imenujejo lesivirana tla, proces izpiranja gline lesivaža oziroma lesivacija. Kot sinonima pogosto zasledimo tudi izraza ilimerizacija in argiluviacija. Po Slovenski klasifikaciji tal (Prus in sod., 2015) izprana tla uvrščamo v razred eluvialno-iluvialnih tal. Po podatkih pedološke karte $1: 25.000$ izprana tla pokrivajo 2,3\% slovenskega ozemlja (TIS/ICPVO, 2017). Najdemo jih na različnih matičnih podlagah, največkrat na uravnanem površju, kjer ni delovanja erozijskih in koluvialnih procesov, $\mathrm{v}$ kombinaciji $\mathrm{z}$ rjavimi pokarbonatnimi tlemi na apnencih in dolomitih.

V prispevku želimo predstaviti morfološke, fizikalne in kemične lastnosti izpranih tal $\mathrm{v}$ Sloveniji, njihovo prostorsko razširjenost, odvisnost od tlotvornih dejavnikov, predvsem od matične podlage, ter primerjavo z izpranimi tlemi v Evropi. Preveriti želimo razvrstitev izpranih tal po WRB klasifikaciji.

\section{MATERIALI IN METODE}

\subsection{Vir in priprava podatkov}

Podatki so bili pridobljeni iz baze Talnega informacijskega sistema Slovenije (TIS/ICPVO, 2017). Pedokartografske enote, ki so vključevale izprana tla, smo izvozili iz atributne tabele Digitalne pedološke karte Slovenije $1: 25.000$ in združili v nov podatkovni sloj (TIS/ICPVO, 2017). Za vsako pedokartografsko enoto smo izračunali površino izpranih tal ter izrisali prostorsko razporeditev. Izračunali smo delež izpranih tal glede na matično podlago in izrisali karto matičnih podlag izpranih tal v Sloveniji (Slika 3). Statistično analizo pedoloških lastnosti smo izvedli na 49 profilih izpranih tal, ki so bili izkopani v sklopu pedološkega kartiranja Slovenije ali drugih raziskav tal v obdobju od 1974 do 1998, za katere so bili na voljo potrebni analitski in opisni morfološki podatki po horizontih in prostorska opredelitev. Lokacije talnih profilov izpranih tal so prikazane na sliki 1 . Za potrebe statističnih analiz smo imena talnih horizontov generalizirali v 5 skupin $\left(\mathrm{O}_{\mathrm{h}} / \mathrm{A}_{\mathrm{h}}, \mathrm{A}, \mathrm{E}, \mathrm{B}_{\mathrm{t}}, \mathrm{BC}\right)$; kriteriji za razvrščanje so prikazani v preglednici 1 . Za grafični prikaz prostorskih podatkov smo uporabili program ArcGIS 10.2.2 for Desktop (ESRI, 2014) in program R (R Development Core Team, 2016). Izris talnih profilov in analizo barv smo izvedli s pomočjo paketa »aqp« (Beaudette in sod., 2013).

Preglednica 1: Skupine posplošenih horizontov 
Table 1: Groups of generalized horizons

\begin{tabular}{ll}
\hline Horizonti & Značilnosti \\
\hline $\mathrm{O}_{\mathrm{h}} / \mathrm{A}_{\mathrm{h}}$ & $\begin{array}{l}\text { Organski horizonti z več kot } 35 \% \text { organske snovi in humusno-akumulativni horizonti z več } \\
\text { kot } 15 \% \text { organske snovi. }\end{array}$ \\
$\mathrm{A}$ & Humusno-akumulativni horizonti z manj kot $15 \%$ organske snovi. \\
$\mathrm{E}$ & $\begin{array}{l}\text { Eluvialni horizonti: v primerjavi } \mathrm{z} \mathrm{B}_{\mathrm{t}} \text { so svetlejše barve, lažje teksture, s slabše izraženo } \\
\text { strukturo in } \mathrm{z} \text { manjšim deležem bazičnih kationov. }\end{array}$ \\
$\mathrm{B}_{\mathrm{t}}$ & Iluvialni horizonti - akumulacija gline, glinene prevleke. \\
$\mathrm{BC}$ & Prehodni horizonti - mineralni del tal v kombinaciji s C horizontom.
\end{tabular}

Prehodni horizonti so bili uvrščeni v skupino glede na prevladujoče lastnosti (primera: AC v A ali EB v E)

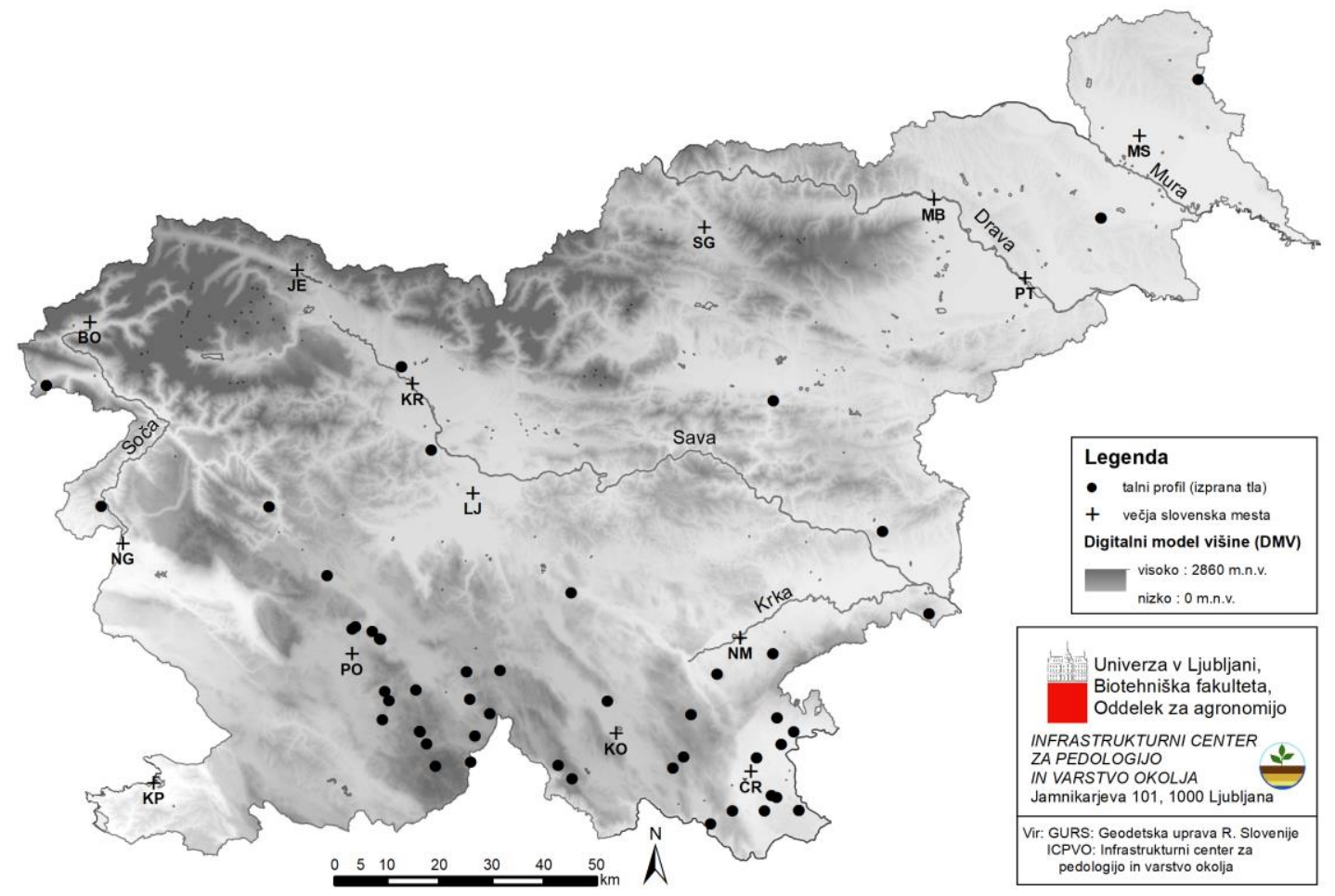

Slika 1: Lokacije talnih profilov izpranih tal (TIS/ICPVO, 2017)

Figure 1: Locations of soil profiles (TIS/ICPVO, 2017)

\subsection{Laboratorijske metode}

Analize fizikalnih in kemičnih lastnosti talnih vzorcev $(\mathrm{n}=213)$ so bile izvedene $\mathrm{v}$ pedološkem laboratoriju Katedre za pedologijo in varstvo okolja. Vzorci so bili zračno posušeni in presejani skozi sito $\mathrm{z} 2 \mathrm{~mm}$ odprtinami. $\mathrm{pH}$ tal je bil izmerjen elektrometrično $\mathrm{v}$ suspenziji tla : ekstrakcijska raztopina $(0,1 \mathrm{M} \mathrm{KCl}$ ali $\left.0,01 \mathrm{M} \mathrm{CaCl}_{2}\right)$ v razmerju $1: 2,5(\mathrm{v} / \mathrm{v})$. Organska snov je bila določena $\mathrm{z}$ mokrim sežigom po modificirani Walkley-Black metodi, tekstura tal (razen v organskih horizontih) je bila določena $\mathrm{s}$ sedimentacijsko pipetno metodo po ameriški teksturni klasifikaciji. Rastlinam dostopni fosfor in kalij sta bila izmerjena po ekstrakciji z amonlaktatom. Skupni dušik je bil analiziran po
Kjeldahlovem postopku s $\mathrm{TiO}_{2}$ kot katalizatorjem. Kationska izmenjalana kapaciteta je bila določena kot vsota bazičnih kationov določenih po ekstrakciji z $1 \mathrm{M}$ amonacetatom $(\mathrm{pH} 7)$ in kislih kationov določenih po modificirani Melichovi metodi (Soil Survey Staff, 1992).

\subsection{Statistična analiza}

Lastnosti 49 talnih profilov smo predstavili $\mathrm{z}$ opisnimi statistikami. Za preverjanje razlik $\mathrm{v} p H$ in deležu bazičnih kationov med rabami tal smo izvedli analizo variance. Statistične analize smo izvedli v programu $R$ (R Development Core Team, 2016), ternarni diagram smo izrisali z orodjem GCDkit 4.0 (Janousek in sod., 
2006). Preglednica 2 prikazuje opisne statistike vseh obravnavanih pedoloških spremenljivk.

Preglednica 2: Opisne statistike pedoloških spremenljivk (49 talnih profilov, 213 horizontov)

Table 2: Descriptive statistics of pedologic variables (49 soil profiles, 213 horizons)

\begin{tabular}{|c|c|c|c|c|c|c|c|c|}
\hline Spremenljivka & Enota & $\mathrm{n}$ & Povprečje & SD & $\mathrm{KV}$ & Mediana & Min & Max \\
\hline pesek & $\%$ & 199 & 12,2 & 9,1 & 0,75 & 9,4 & 0,5 & 59,3 \\
\hline melj & $\%$ & 199 & 53,1 & 15,6 & 0,29 & 56,5 & 5,2 & 78,9 \\
\hline glina & $\%$ & 199 & 34,8 & 16,0 & 0,46 & 30,5 & 3,5 & 92,0 \\
\hline $\mathrm{pH}_{\mathrm{KCl}}$ & & 207 & 4,6 & 0,8 & 0,18 & 4,3 & 2,9 & 6,8 \\
\hline organska snov & $\%$ & 184 & 6,0 & 10,2 & 1,70 & 2,0 & 0,2 & 70,8 \\
\hline $\mathrm{C}_{\mathrm{org}}$ & $\%$ & 184 & 3,5 & 5,9 & 1,70 & 1,5 & 0,1 & 41,0 \\
\hline $\mathrm{P}_{2} \mathrm{O}_{5}$ & $\mathrm{mg} / 100 \mathrm{~g}$ & 86 & 4,4 & 6,9 & 1,54 & 2,2 & 0,1 & 44,5 \\
\hline $\mathrm{K}_{2} \mathrm{O}$ & $\mathrm{mg} / 100 \mathrm{~g}$ & 101 & 11,3 & 10,9 & 0,97 & 7,5 & 1,2 & 71,1 \\
\hline $\mathrm{N}$ & $\%$ & 161 & 0,2 & 0,3 & 1,21 & 0,1 & $<0,1$ & 100,2 \\
\hline $\mathrm{CN}$ & & 161 & 13,9 & 9,1 & 0,66 & 13,2 & 0,6 & 1,7 \\
\hline izmen. $\mathrm{Ca}^{2+}$ & $\mathrm{mmol}_{\mathrm{c}} / 100 \mathrm{~g}$ & 199 & 8,5 & 8,5 & 0,99 & 5,8 & 0,1 & 62,3 \\
\hline izmen. $\mathrm{Mg}^{2+}$ & $\mathrm{mmol}_{\mathrm{c}} / 100 \mathrm{~g}$ & 199 & 1,6 & 1,8 & 1,11 & 0,9 & $<0,1$ & 9,2 \\
\hline izmen. $\mathrm{K}^{+}$ & $\mathrm{mmol}_{\mathrm{c}} / 100 \mathrm{~g}$ & 199 & 0,2 & 0,2 & 0,78 & 0,2 & $<0,1$ & 0,9 \\
\hline izmen. $\mathrm{Na}^{+}$ & $\mathrm{mmol}_{\mathrm{c}} / 100 \mathrm{~g}$ & 199 & 0,1 & 0,1 & 0,73 & 0,1 & $<0,1$ & 0,6 \\
\hline $\begin{array}{l}\text { Vsota } \\
\text { kationov }\end{array}$ & bazičnih $\mathrm{mmol}_{\mathrm{c}} / 100 \mathrm{~g}$ & 199 & 10,4 & 9,3 & 0,89 & 8,1 & 0,3 & 65,8 \\
\hline KIK & $\mathrm{mmol}_{\mathrm{c}} / 100 \mathrm{~g}$ & 199 & 24,9 & 11,5 & 0,46 & 22,5 & 17,3 & 99,9 \\
\hline $\mathrm{KIK}_{\mathrm{glina}} *$ & $\mathrm{mmol}_{\mathrm{c}} / 100 \mathrm{~g}$ & 80 & 52,4 & 14,9 & 0,28 & 48,7 & 26,6 & 112,0 \\
\hline $\mathrm{KIK}_{\mathrm{glina}} * *$ & $\mathrm{mmol}_{\mathrm{c}} / 100 \mathrm{~g}$ & 80 & 45,8 & 12,1 & 0,26 & 42,9 & 19,9 & 98,7 \\
\hline $\mathrm{V} * * *$ & $\%$ & 199 & 38,6 & 22,7 & 0,59 & 39,2 & 1,8 & 83,5 \\
\hline
\end{tabular}

$\mathrm{SD}$ - standardna deviacija, KV - koeficient variacije, Min - minimum, Max - maksimum

* $\mathrm{KIK}_{\mathrm{glina}}:(\mathrm{KIK} / \% \mathrm{gline}) * 100$ (vključeni le iluvialni horizonti)

** $\mathrm{KIK}_{\text {glina }}$ : $\left(\mathrm{KIK}-\left(\% \mathrm{C}_{\text {org }} * 4,5\right) * 100\right) / \%$ gline (po Camargo in sod., 1986) (vključeni le iluvialni horizonti)

** $\mathrm{V}$ - delež bazičnih kationov na sorptivnem delu tal

\section{REZULTATI IN DISKUSIJA}

\subsection{Razširjenost izpranih tal v Sloveniji}

Izprana tla pokrivajo $2,3 \%$ Slovenije. Najbolj so razširjena $\mathrm{v}$ jugovzhodnem delu države, še posebej $\mathrm{v}$ Beli krajini, kjer leži $60 \%$ vseh izpranih tal. Izprana tla najdemo tudi v Dolenjskem podolju (15,3\%), na Gorenjskem (14,1\%), v Ribniško-Kočevskem podolju $(6,4 \%)$ in $\mathrm{v}$ manjšem obsegu na nekaterih drugih območjih Slovenije (Slika 2). Večina pedokartografskih enot izpranih tal se pojavlja med Belo krajino in Jesenicami (Slika 2), medtem ko je bilo največ profilov izpranih tal izkopanih $\mathrm{v}$ južnem delu Slovenije (Notranjska, Dolenjska). Neujemanje med lokacijami pedokartografskih enot izpranih tal (Slika 3) in številom dokumentiranih profilov izpranih tal (Slika 2), je posledica večjega števila raziskav na območju južnega dela Slovenije, kjer se izprana tla pojavljajo v združbi z rjavimi pokarbonatnimi tlemi in rendzinami. Ker prevladujejo mlajše razvojne oblike tal, izprana tla niso navedena $\mathrm{v}$ imenu pedokartografskih enot. $\mathrm{V}$ splošnem velja, da so procesi premeščanja gline in drugih $\mathrm{v}$ vodi topnih snovi $\mathrm{v}$ tleh zelo odvisni od količine padavin, vendar na območju Alp, kljub ekstremnim količinam padavin, izpranih tal ne zasledimo, saj na razvoj tal bistveno vplivajo erozijski in koluvialni procesi, zaradi česar tam prevladujejo mlada tla (litosoli, rendzine). Znaki izpiranja se pri nas $\mathrm{v}$ goratih območjih $\mathrm{z}$ veliko padavinami izrazijo le $\mathrm{v}$ globokih tleh na uravnanih platojih (na primer Pokljuka). 


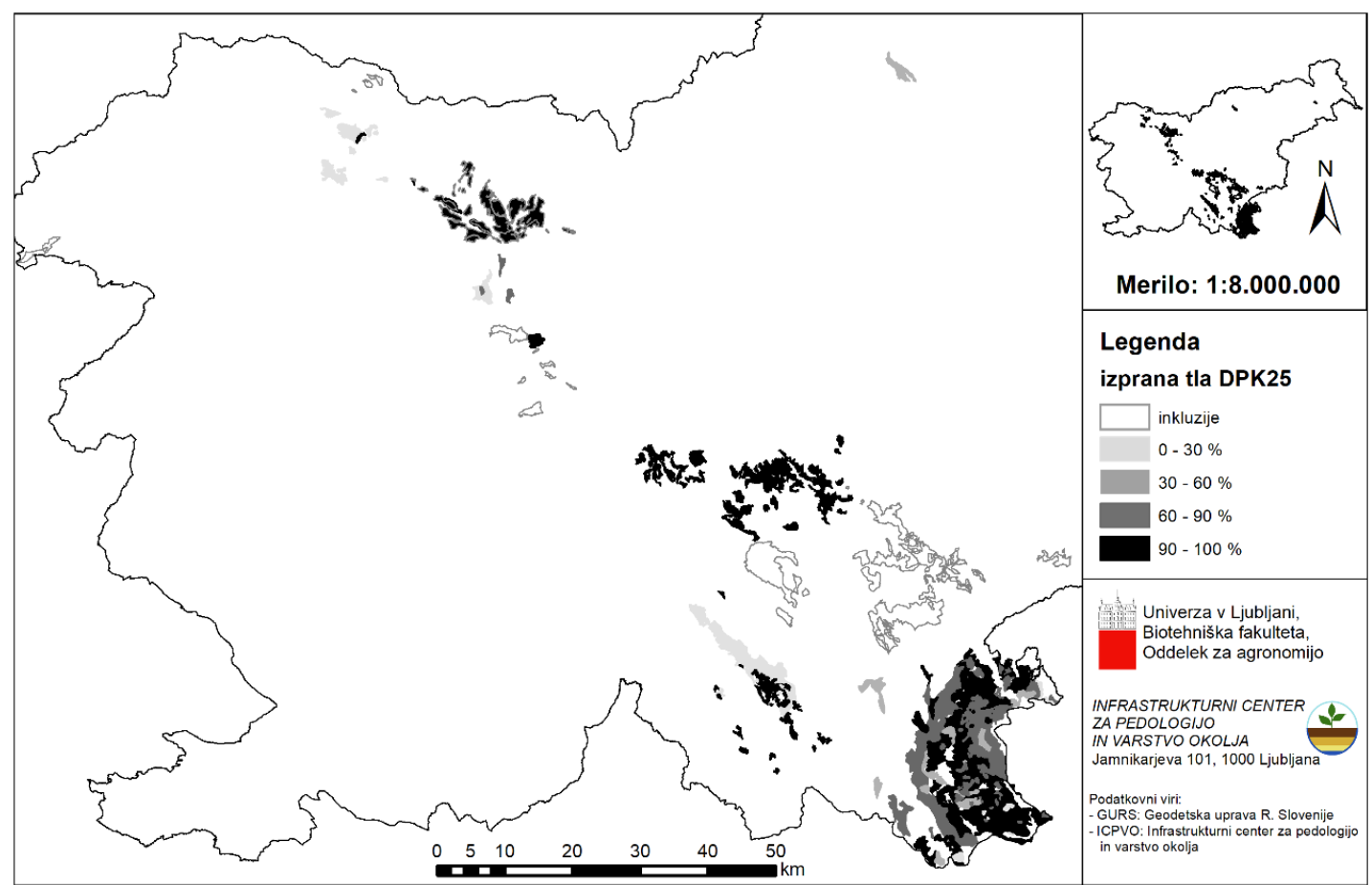

Slika 2: Zastopanost izpranih tal v Sloveniji po posameznih pedokartografskih enotah pedološke karte $1: 25.000$ (TIS/ICPVO, 2017)

Figure 2: Spatial distribution of leached soils in Slovenia according to percentage of their occurrence in pedocartographic unit (TIS/ICPVO, 2017)

Izprana tla se $\mathrm{V}$ večini pojavljajo na apnencu in dolomitu $(60,7 \%) \quad \mathrm{v}$ združbi $\mathrm{z}$ rendzinami in kambičnimi tlemi. Pojavljajo se tudi na sedimentih $(25,6 \%)$ in konglomeratu $(12,3 \%)$, v majhnem deležu na nekarbonatnih sedimentnih kamninah $(0,7 \%)$, moreni $(0,4 \%)$ in flišnih kamninah $(0,3 \%)$. Slika 3 prikazuje matične podlage, na katerih se pojavljajo izprana tla. Pri izpranih tleh na klastičnih sedimentnih kamninah lahko $\mathrm{k}$ teksturni razliki med horizonti prispeva tudi razlika $\mathrm{v}$ granulometrijski sestavi posameznih plasti sedimentnih kamnin oziroma kamninska nezveznost. Obstaja možnost, da nekateri profili na takih kamninah ne ustrezajo kriteriju izpranih tal, vendar tega nismo mogli preveriti, ker večinoma $\mathrm{v}$ bazi pedološke karte ni na voljo podatka o pojavljanju glinenih prevlek na strukturnih agregatih, ki nedvoumno dokazujejo eluvialno-iluvialne procese v tleh. 


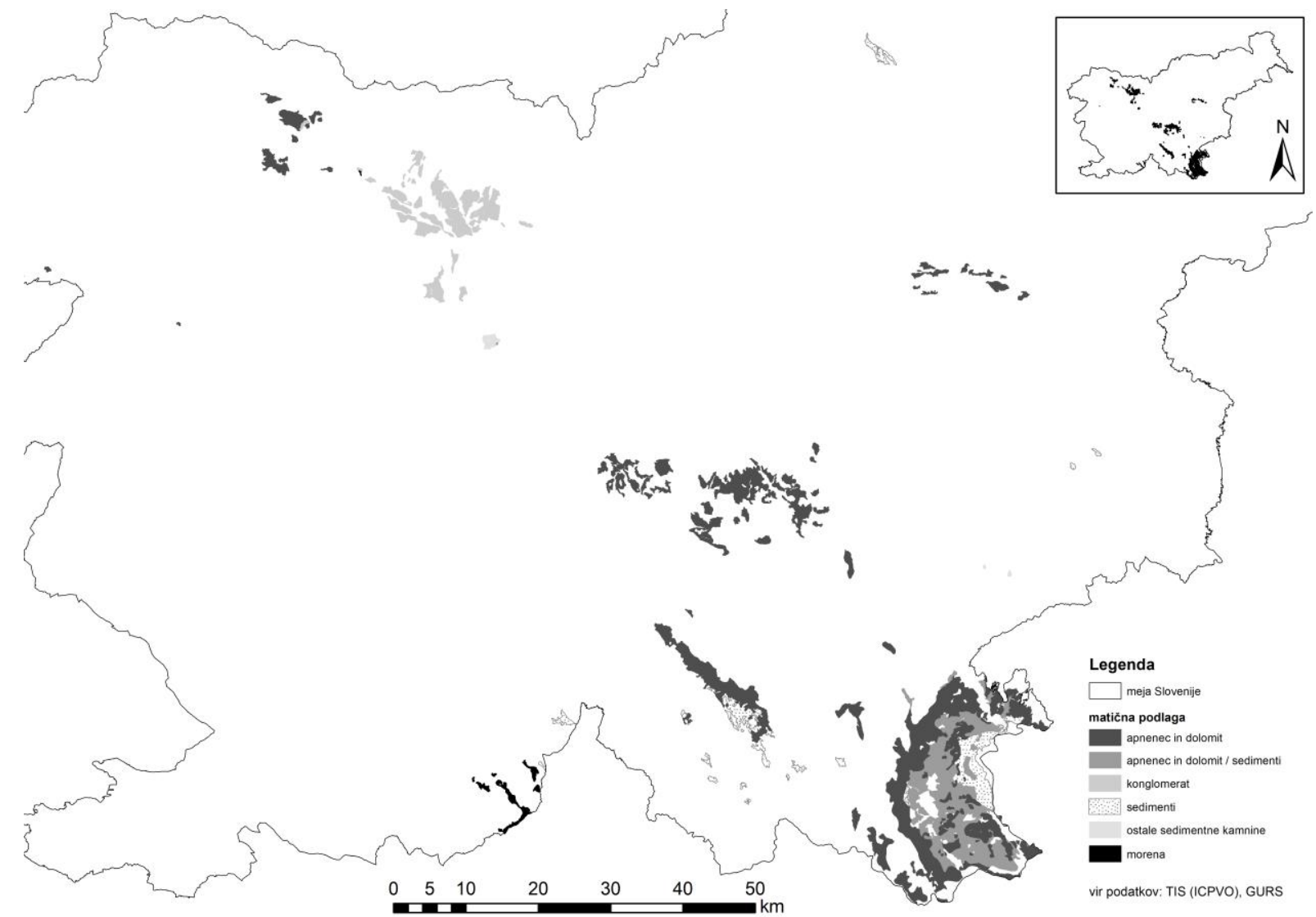

Slika 3: Matične podlage na katerih se pojavljajo izprana tla v Sloveniji; Digitalna pedološka karta Slovenije (TIS/ICPVO, 2017)

Figure 3: Different parent materials upon which leached soils appear; Digital soil map of Slovenia (TIS/ICPVO, 2017)

\subsection{Klasifikacija izpranih tal}

Osnovni diagnostični kriterij Slovenske klasifikacije tal (Prus in sod., 2015) za uvrstitev tal v eluvialno-iluvialni razred je prisotnost eluvialnega horizonta, ki ima $\mathrm{v}$ primerjavi z iluvialnim svetlejšo barvo, lažjo teksturo, slabšo strukturno obstojnost in manjši delež bazičnih kationov. Navodilo zahteva $20 \%$ več gline $v B_{t}$ horizontu glede na E, a ne opredeljuje ali gre za relativno ali absolutno razliko. Večina profilov izpranih tal $\mathrm{v}$ bazi pedološke karte ne izkazuje tako velike absolutne razlike $\mathrm{v}$ teksturi. Izprana tla so bila $\mathrm{v}$ času intenzivnega pedološkega kartiranja opredeljena na osnovi identifikacije teksturne razlike med $B_{t}$ in $E$ horizontom s prstnim poskusom, kot je bilo zapisano $\mathrm{v}$ takrat veljavni Jugoslovanski klasifikaciji tal (Škorič in sod., 1985). Statistična analiza profilov izpranih tal je pokazala, da imajo $\mathrm{v}$ povprečju $\mathrm{B}_{\mathrm{t}}$ horizonti, ki ležijo neposredno pod E horizonti, za 1,6-krat več gline. Kar $75 \%$ izpranih tal dosega količnik večji od 1,38, kar se približa pogojem WRB klasifikacije (IUUS Working group WRB, 2015). WRB kriterij je različen za različno količino gline v E horizontu (Preglednica 3). Pri vsebnosti gline med 10 in $50 \%$, kar je najpogosteje $\mathrm{v}$ Sloveniji, je faktor med $B_{t}$ in E 1,4. Preverili smo tudi kriterije nemške, avstrijske in ameriške klasifikacije (Preglednica 3) in ugotovili, da večina proučevanih talnih profilov po teksturi ustreza kriterijem za izprana tla. 
Preglednica 3: Diagnostični kriteriji za argični $\left(B_{t}\right)$ horizont (Turniški, 2016)

Table 3: Diagnostic criteria for argic $\left(B_{t}\right)$ horizons (Turniški, 2016)

\begin{tabular}{|c|c|c|}
\hline Klasifikacija & Glavni kriterij (teksturna diferenciacija) & Vir \\
\hline $\begin{array}{l}\text { Jugoslovanska } \\
\text { klasifikacija tal }\end{array}$ & $\begin{array}{l}\text { Razlika v vsebnosti gline med horizontoma mora biti s prstnim } \\
\text { poskusom zaznavna v prid } \mathrm{B}_{\mathrm{t}} \text { horizonta. }\end{array}$ & Škorič in sod., 1985 \\
\hline $\begin{array}{l}\text { Slovenska } \\
\text { klasifikacija tal }\end{array}$ & $\begin{array}{l}\text { V iluvialnem horizontu mora biti najmanj } 20 \% \text { več gline kot v E } \\
\text { horizontu. }\end{array}$ & Prus in sod., 2015 \\
\hline $\begin{array}{l}\text { Mednarodna } \\
\text { klasifikacija tal } \\
\text { (WRB) }\end{array}$ & $\begin{array}{l}\text { Če ima E horizont manj kot } 10 \% \text { gline, jo mora imeti argični } \\
\text { horizont vsaj } 4 \% \text { več. } \\
\text { Če ima E horizont med } 10 \text { in } 50 \% \text { gline, mora imeti argični } \\
\text { horizont vsaj za } 1,4 x \text { več gline. } \\
\text { Če ima E horizont več kot } 50 \% \text { gline, mora imeti argični } \\
\text { horizont vsaj } 20 \% \text { več gline. }\end{array}$ & $\begin{array}{l}\text { IUUS Working group } \\
\text { WRB, } 2015\end{array}$ \\
\hline $\begin{array}{l}\text { Nemška } \\
\text { klasifikacija tal }\end{array}$ & 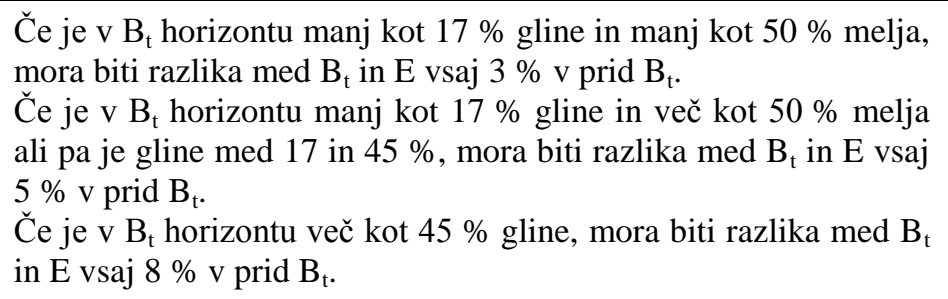 & $\begin{array}{l}\text { Arbeitskreis } \\
\text { Bodensystematik } \ldots \text { für } \\
1998\end{array}$ \\
\hline $\begin{array}{l}\text { Avstrijska } \\
\text { klasifikacija tal }\end{array}$ & $\begin{array}{l}\mathrm{B}_{\mathrm{t}} \text { horizont mora vsebovati vsaj } 25 \% \text { gline in za najmanj } 15 \% \\
\text { (relativno) več gline od E horizonta. }\end{array}$ & Nestroy in sod. 2011 \\
\hline $\begin{array}{l}\text { Ameriška } \\
\text { klasifikacija tal } \\
\text { (USDA Soil } \\
\text { Taxonomy) }\end{array}$ & $\begin{array}{l}\breve{C} \text { ima E horizont manj kot } 15 \% \text { gline, jo mora imeti argični }\left(\mathrm{B}_{\mathrm{t}}\right) \\
\text { horizont vsaj } 3 \% \text { več. } \\
\text { Če ima E horizont med } 15 \text { in } 40 \% \text { gline, mora imeti argični }\left(\mathrm{B}_{\mathrm{t}}\right) \\
\text { horizont vsaj za } 1,2 \mathrm{x} \text { več gline. } \\
\text { Če ima E horizont več kot } 40 \% \text { gline, mora imeti argični }\left(\mathrm{B}_{\mathrm{t}}\right) \\
\text { horizont vsaj } 8 \% \text { več gline. }\end{array}$ & Keys to Soil ..., 2014 \\
\hline
\end{tabular}

Proučevana tla smo klasificirali tudi po WRB klasifikaciji (IUUS Working group WRB, 2015). Pregled je pokazal, da diagnostične zahteve za argični horizont dosega le 40 od 49 profilov izpranih tal. Izprana tla smo uvrstili $\mathrm{v}$ dve Referenčni talni skupini, med luvisole $(\mathrm{n}=22)$ in alisole $(\mathrm{n}=18)$. Luvisoli se običajno pojavljajo na apnencu in dolomitu in so se razvili iz evtričnih rjavih ali rjavih pokarbonatnih tal, ki so pogosta v Sloveniji. Argični horizonti v luvisolih so evtrični (zasičenost $\mathrm{z}$ bazičnimi kationi $>50 \%$ ) in imajo veliko vsebnost visoko aktivnih glin, ki prispevajo $\mathrm{k}$ večji kationski izmenjalni kapaciteti $\left(\mathrm{KIK}_{\text {glina }}>24 \mathrm{mmol}_{\mathrm{c}} / 100 \mathrm{~g}\right.$ gline $) . \mathrm{V}$ razmerah intenzivnega izpiranja se lahko luvisoli razvijejo $\mathrm{v}$ alisole. Slednji lahko nastanejo tudi iz distričnih rjavih tal. Za razliko od luvisolov imajo argični horizonti $\mathrm{v}$ alisolih majhno zasičenost $\mathrm{z}$ bazičnimi kationi $(<50 \%)$. Glede na navedbe $\mathrm{v}$ literaturi, ki že povzema podatke Pedološke karte 1:25.000 (Urbančič in sod., 2005; Vidic in sod., 2015; Vrščaj in sod., 2017), smo pričakovali, da se bo del proučevanih tal uvrstilo med akrisole, vendar kationska izmenjalna kapaciteta preračunana na delež gline in delež bazičnih kationov ne dokazujejo prisotnost akrisolov. Prav tako se noben profil ni uvrstil med liksisole. Liksisoli in akrisoli sta referenčni talni skupini katerih argični horizonti so za razliko od luvisolov in alisolov močneje prepereli, kar se kaže tudi v večji vsebnosti kaolinita (Blume in sod., 2016). Glede na kriterij WRB bi morali imeti argični horizonti kationsko izmenjalno kapaciteto manjšo od $24 \mathrm{mmol}_{\mathrm{c}} / 100 \mathrm{~g}$ gline $\left(\mathrm{KIK}_{\mathrm{glina}}\right)$. Takšna tla se $\mathrm{v}$ Sloveniji pojavljajo $\mathrm{v}$ omejenem obsegu, liksisoli na območju Snežnika (Kobal, 2011; Turniški, 2016) in akrisoli na Dolenjskem (Kralj, 2008), vendar o njihovem razvoju in prostorski razporeditvi vemo bolj malo. Naše ugotovitve glede pojavnosti luvisolov, alisolov, akrisolov in lixisolov so primerljive $\mathrm{z}$ ugotvitvami raziskovalcev v Italiji, kjer se najpogosteje pojavljajo luvisoli $(12,8 \%)$ in alisoli $(0,17 \%)$, medtem ko se akrisoli $(0,017 \%)$ in lixisoli $(0,004 \%)$ pojavljajo zelo redko (Costantini in sod., 2013). Po Soil Atlas of Europe (2005) se akrisoli in alisoli v omejenem obsegu $(<1 \%)$ pojavljajo $\mathrm{v}$ vlažnejših delih Mediterana $\mathrm{v}$ združbi z luvisoli, vendar sta njihov razvoj in prostorska razporejenost slabo poznana, zato so potrebne nadaljnje raziskave. 


\subsection{Morfološke lastnosti izpranih tal}

Izprana tla so starejše razvojne oblike tal, zato smo pričakovali globoke talne profile. Statistični pregled podatkov je pokazal velik razpon v globini tal (Slika 4). Najbolj plitva tla merijo $40 \mathrm{~cm}$, najgloblja $429 \mathrm{~cm} .75 \%$ tal je globljih od $75 \mathrm{~cm}$, zato jih po kriterijih Slovenske klasifikacije tal (Prus in sod., 2015) uvrščamo med globoka ali zelo globoka tla. Trije talni profili so globlji od $210 \mathrm{~cm}$. Pri globini tal je potrebno upoštevati, da večina profilov ni bilo izkopanih do matične podlage, zato spodnje globine brez $\mathrm{C}$ ali $\mathrm{R}$ horizonta niso zanesljiv podatek. Pri globokih tleh se je za potrebe klasifikacije običajno izkopalo profil le od 100 do $150 \mathrm{~cm}$ globine. V večini izpranih tal si horizonti sledijo $\mathrm{v}$ tipičnem (poenostavljenem) zaporedju A-E- $\mathrm{B}_{\mathrm{t}}$, pogosto se znotraj profila nahaja več horizontov $\mathrm{s}$ pedogenetskimi znaki izpiranja, ki se razlikujejo po stopnji izraženosti (npr.: A-E $\left.\mathrm{E}_{1}-\mathrm{E}_{2}-\mathrm{B}_{\mathrm{t} 1}-\mathrm{B}_{\mathrm{t} 2}\right)$. Najdebelejši so $\mathrm{B}_{\mathrm{t}}$ horizonti (mediana $=41,5 \mathrm{~cm}$ ), sledijo $\mathrm{E}$ (mediana $=27 \mathrm{~cm})$, A $($ mediana $=12 \mathrm{~cm})$ in $\mathrm{O}_{\mathrm{h}} / \mathrm{A}_{\mathrm{h}}$ horizonti $($ mediana $=5 \mathrm{~cm}) \quad($ Slika 4$)$. Velika debelina $B_{t}$ horizontov in skupna globina tal nakazujejo, da gre za stara tla (Vidic, 1989).

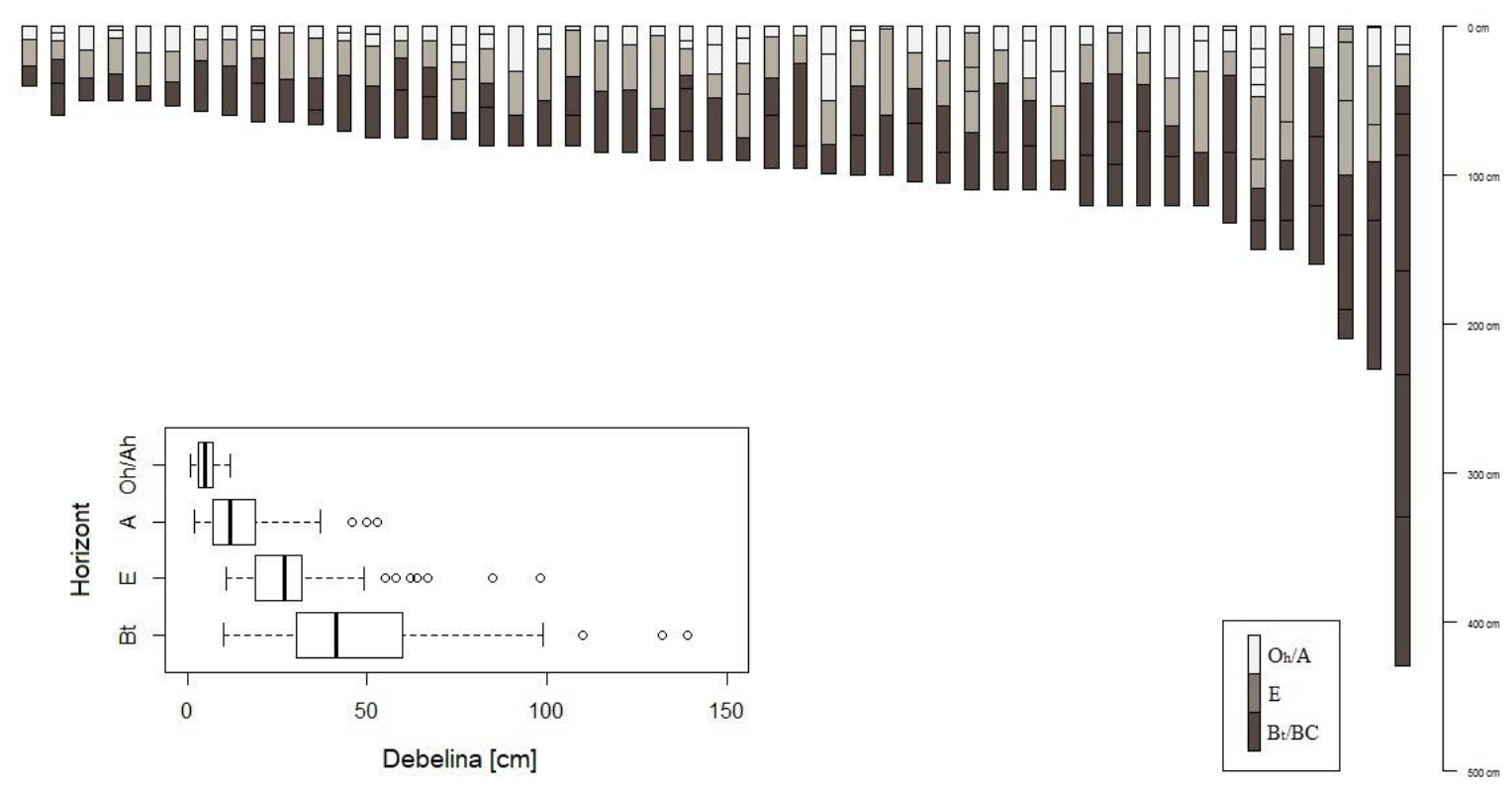

Slika 4: Prikaz talnih profilov izpranih tal razporejenih po globini in okvir z ročaji (odebeljena črta = mediana; okvir $=$ kvartil $25 \%, 75 \%$; sp. in zg. ročaj = min, max; krožec = osamelec) za skupno debelino istovrstnih horizontov znotraj talnega profila (brez vrednosti za $\mathrm{B}_{\mathrm{t}}$ horizont globine $389 \mathrm{~cm}$ )

Figure 4: Soil profiles of leached soils arranged by depth and boxplots (black thickened line $=$ median; rectangles $=$ quartiles $25 \%, 75 \%$; ranges $=\min$, max; circles $=$ outliers) for horizon thickness within soil profile (horizons of the same kind within soil profile were united; the thickest $B_{t}$ horizon $(389 \mathrm{~cm})$ is not included)

Za eluvialne horizonte sta značilni sferična in poliedrična struktura. Talni agregati $\mathrm{v}$ E horizontih so $\mathrm{v}$ večini primerov slabše izraženi in manj obstojni, predvsem na račun izpiranja bazičnih kationov $\mathrm{v}$ spodnje plasti. $\mathrm{V} \mathrm{B}_{\mathrm{t}}$ in $\mathrm{BC}$ horizontih prevladuje poliedrična struktura, ki je značilna za kambične horizonte tal, nastalih na apnencih in dolomitih (Vidic in sod., 2015). $\mathrm{V} \mathrm{O}_{\mathrm{h}} / \mathrm{A}_{\mathrm{h}}$ horizontih prevladuje mrvičasta struktura, $\mathrm{v}$ A horizontih grudičasta in oreškasta. Spodnji $B_{t}$ horizonti so običajno gostejši in/ali bolj zbiti, medtem ko so $\mathrm{E}$ horizonti drobljivi in manj gosti. Humusno akumulativni horizont je rahel in/ali drobljiv, organski horizont $\mathrm{v}$ večini rahel. Novotvorbe $\mathrm{v}$ obliki glinenih prevlek se pojavljajo $\mathrm{v}$ iluvialnih horizontih, kar je znak za premeščanje gline. Kot posledica kratkotrajnega zastajanja vode se $\mathrm{v}$ tleh $\mathrm{v} \mathrm{B}_{\mathrm{t}}$ horizontih tvorijo Fe in Mn prevleke in konkrecije. Barvni odtenki iluvialnih horizontov so v razponu od $2.5 \mathrm{YR}$ do $7.5 \mathrm{YR}$, medtem ko v zgornjih horizontih prevladuje odtenek 10YR. Povprečna barva $B_{t}$ horizontov je $5 \mathrm{YR} 4 / 5$, 5YR 4/4 v BC, 10YR 5/5 v E, 10YR 4/3 v A in 10YR 3/2 v $\mathrm{O}_{\mathrm{h}} / \mathrm{A}_{\mathrm{h}}$ horizontih (Preglednica 4). Diagnostični horizont izpranih tal je glede na kriterije Slovenske klasifikacije tal (Prus in sod., 2015) eluvialni (E) horizont, ki ga prepoznamo po svetlejši barvi. Analiza barv horizontov je potrdila, da so E horizonti svetlejši od ostalih. $\mathrm{V} \mathrm{B}_{t}$ horizontih prevladujejo rdečerjavi barvni odtenki, kar lahko razlagamo s prisotnostjo $\mathrm{Fe}$ oksidov, ki se kopičijo $\mathrm{v}$ iluvialnih horizontih. Skeleta je v izpranih tleh malo. Večinoma se pojavlja le $\mathrm{v}$ spodnjih $\mathrm{B}_{\mathrm{t}}$ horizontih tal na apnencu in dolomitu, na konglomeratu in na flišnih kamninah. 
Preglednica 4: Morfološke lastnosti po skupinah horizontov

Table 4: Morphological characteristics of soil by groups of horizon

\begin{tabular}{|c|c|c|c|c|c|}
\hline $\begin{array}{l}\text { Horizont } \\
\text { (skupina) }\end{array}$ & $\mathrm{n}$ & Barva* & Struktura & Konzistenca & Novotvorbe \\
\hline $\mathrm{O}_{\mathrm{h}}+\mathrm{A}_{\mathrm{h}}$ & 21 & $10 \mathrm{YR} 3 / 2$ & mrvičasta & rahla & - \\
\hline A & 50 & $10 Y R 4 / 3$ & grudičasta, oreškasta & rahla, zelo drobljiva & - \\
\hline $\mathrm{E}$ & 58 & $10 Y R 5 / 5$ & poliedrična, oreškasta & drobljiva, gosta & - \\
\hline $\mathrm{B}_{\mathrm{t}}$ & 78 & $5 \mathrm{YR} 4 / 5$ & poliedrična & gosta, zbita & $\mathrm{Fe}, \mathrm{Mn}$ prevleke in \\
\hline $\mathrm{BC}$ & 6 & $5 Y R 4 / 4$ & poliedrična & gosta & konkrecije, glinene prevleke \\
\hline
\end{tabular}

\subsection{Kemične in fizikalne lastnosti izpranih tal}

Glede na povprečno teksturo profila so izprana tla $\mathrm{v}$ večini opredeljena kot ilovnata $(\mathrm{n}=27)$ ali glinasta $(\mathrm{n}=$ 18), v štirih primerih meljasta tla. Vsebnost peska $\mathrm{v}$ izpranih tleh variira med 1 in $59 \%$, melja med 5 in $79 \%$ in gline med 9 in $92 \%$. V vseh profilih se kaže teksturna razlika. $\mathrm{B}_{\mathrm{t}}$ in $\mathrm{BC}$ horizonti imajo značilno večjo vsebnost gline $\mathrm{v}$ primerjavi $\mathrm{z} \mathrm{E}$ horizonti. Prevladujoči teksturni razredi po skupinah horizontov so prikazani $\mathrm{v}$ preglednici 5 . Izprana tla so pretežno sestavljena iz gline $(<2 \mu \mathrm{m})$ in melja $(2-50 \mu \mathrm{m})$. V E horizontih je mediana vsebnosti gline $28,4 \%$ in vsebnosti melja $61,4 \%$, medtem ko je v $B_{t}$ horizontih mediana vsebnosti gline 46,6\% in vsebnosti melja $42 \%$ (Preglednica 5). Velika vsebnost gline v Bt horizontih je pričakovana, saj se večina profilov nahaja na matičnih podlagah apnenec ali dolomit, kar je značilno tudi za izprana tla na Hrvaškem (povprečje 48.5 \%) (Bašić in sod. 2003), na italijanskem krasu (mediana 39\%) (Costantini in sod., 2013) in v Španiji (25-50\%) (Carballas in sod., 2016). Za izprana tla srednje in vzhodne Evrope, ki se pojavljajo na puhlici in drugih sedimentih je značilno več melja in manj gline (Kühn in sod., 2006; Blume in sod., 2016). Slika 5 jasno pokaže teksturno razliko $\mathrm{v}$ izpranih tleh. Peska je $\mathrm{v}$ tleh relativno malo (mediana < 12,1\%), razen $\mathrm{v} B C$ horizontih zaradi vpliva matične podlage. V E horizontu neposredno nad iluvialnim horizontom je povprečna vsebnost gline $28,5 \%, \mathrm{v} \mathrm{B}_{\mathrm{t}} 146,1 \%$ (Slika 5). $\mathrm{B}_{\mathrm{t}} 1$ horizont, ki leži neposredno pod $\mathrm{E}$ horizontom, ima $\mathrm{V}$ povprečju za 1,63-krat več gline kot $\mathrm{E}$ horizont. $75 \%$ tal ima količnik vsebnosti gline med $\mathrm{B}_{\mathrm{t}} 1$ in $\mathrm{E}$ horizontom večji od 1,38. Najmanjši količnik $\mathrm{v}$ vsebnosti gline med $\mathrm{B}_{\mathrm{t}}$ in $\mathrm{E}$ horizontom za tla, ki so $\mathrm{v}$ bazi pedoloških profilov opredeljena kot izprana, je 1,13 .

Preglednica 5: Prevladujoči teksturni razredi in mediane vsebnosti peska, melja in gline po horizontih

Table 5: Prevailing textural classes and medians of content of sand, silt and clay by horizon

\begin{tabular}{l|l|l|l|l}
\hline \multirow{2}{*}{ Horizont } & Prevladujoči & Mediana (min-max) & \\
\cline { 3 - 5 } & teksturni razredi & pesek $(\%)$ & melj $(\%)$ & glina $(\%)$ \\
\hline A $(\mathrm{n}=49)$ & MI, MGI & $12,1(1,7-45,6)$ & $68,1(23,4-78,9)$ & $20,4(10,6-31,7)$ \\
$\mathrm{E}(\mathrm{n}=58)$ & MI, MGI, GI & $9,1(2,3-59,3)$ & $61,4(16,3-76,0)$ & $28,4(8,90-48,1)$ \\
$\mathrm{B}_{\mathrm{t}}(\mathrm{n}=78)$ & MGI, MG, G & $7,8(0,5-43,7)$ & $42,0(5,2-63,7)$ & $46,6(21,8-92,0)$ \\
$\mathrm{BC}(\mathrm{n}=6)$ & MG, G & $18,2(4,2-37,4)$ & $37,8(29,9-42,7)$ & $47,7(23,3-55,3)$ \\
\hline
\end{tabular}




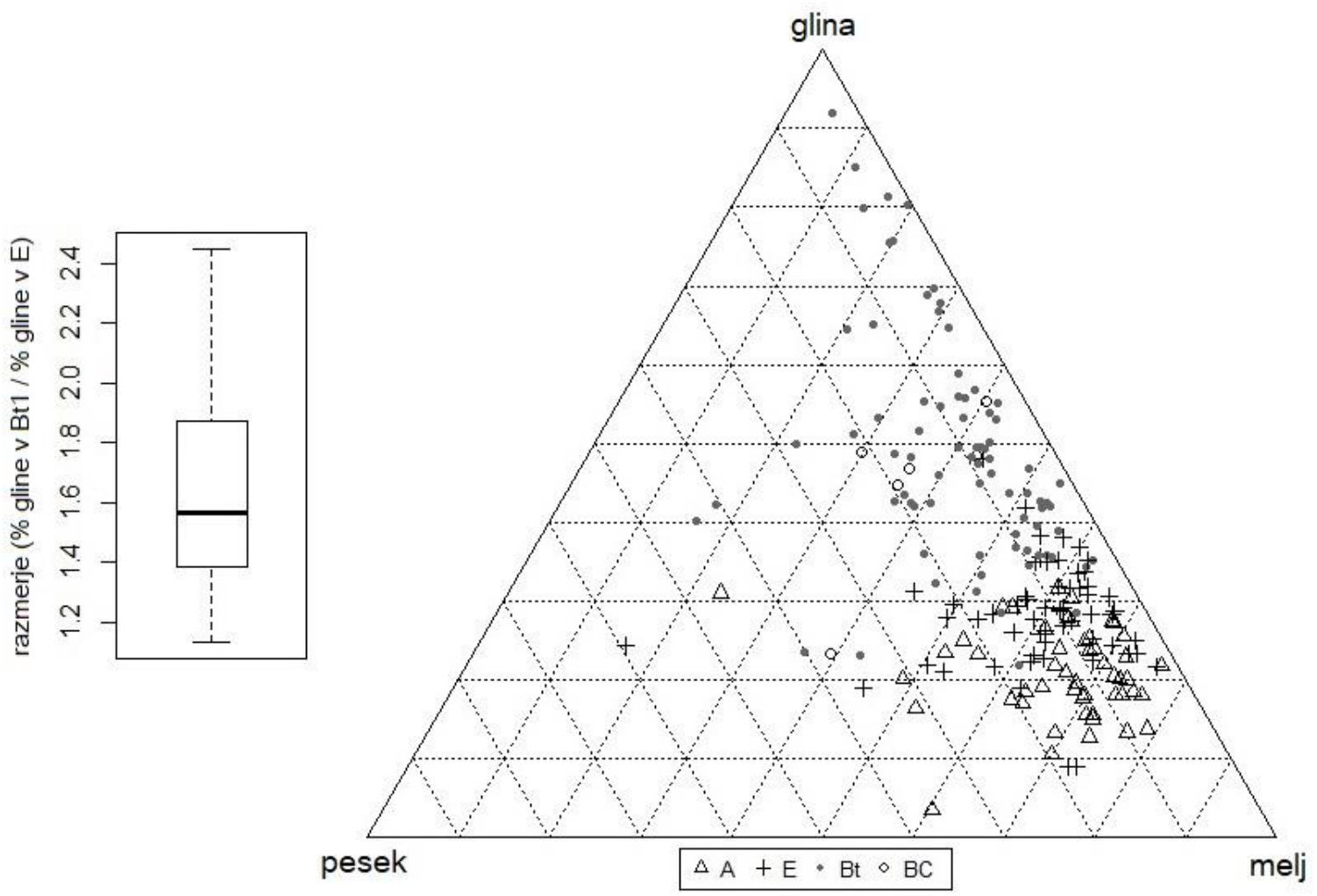

Slika 5: Okvir z ročaji (odebeljena črta $=$ mediana; okvir $=$ kvartil $25 \%, 75 \%$; sp. in zg. ročaj $=\min , \max$; krožec $=$ osamelec) za prikaz razmerja vsebnosti gline med $B_{t 1}$ in $E$ horizontom $(n=49$, levo $)$ in teksturni podatki horizontov izpranih tal, prikazani na ternarnem diagramu (pesek-glina-melj)

Figure 5: The box plot (black thickened line $=$ median; rectangles $=$ quartiles $25 \%, 75 \%$; ranges $=$ min, $\max$; circles $=$ outliers) of the ratio of clay content $-\mathrm{B}_{\mathrm{t} 1} / \mathrm{E}(\mathrm{n}=49$, left $)$ and ternary diagram of textural composition of leached soil (all horizons, right)

$\mathrm{pH}$ vrednosti so $\mathrm{v}$ razponu od 2,9 do 6,8 . Izprana tla imajo običajno nizek $\mathrm{pH}, \mathrm{pH}$ vrednosti blizu nevtralnega območja zasledimo samo na dnu profila (spodnji $\mathrm{B}_{\mathrm{t}}$ horizonti) in $\mathrm{v}$ stiku $\mathrm{z}$ matično podlago (BC horizonti), kot posledico akumulacije bazičnih kationov in vpliva karbonatne matične podlage; povprečna vrednost $\mathrm{pH}$ v BC horizontih je 5,7. V organskih in Ah horizontih je povprečna $\mathrm{pH}$ vrednost 4,4 , deloma kot posledica surovega humusa, deloma zaradi izpiranja bazičnih kationov, kar je značilno za $E$ horizonte, kjer je povprečna vrednost $\mathrm{pH} \quad 4,4 . \quad \mathrm{V} \quad \mathrm{B}_{\mathrm{t}}$ horizontih je povprečna vrednost $\mathrm{pH}$ 4,6. Po WRB klasifikaciji (IUUS Working group WRB, 2015) so proučevani profili uvrščeni med luvisole in alisole. Slika 6 prikazuje razlike med $B_{t}$ in $E$ horizonti znotraj posamezne skupine tal. $\mathrm{Za}$ argične horizonte $\mathrm{v}$ luvisolih je značilna zasičenost $\mathrm{z}$ bazičnimi kationi nad $50 \%$, medtem ko je zasičenost pri alisolih manjša od $50 \%$, kar se kaže tudi $v$ razlikah $\mathrm{pH}$ vrednosti $\mathrm{B}_{\mathrm{t}}$ horizontov med obema skupinama. Očitne so razlike med $B_{t}$ in $E$ horizonti v luvisolih, kjer argični horizonti še niso tako močno izprani. Pri alisolih je slika drugačna, ker je argični horizont osiromašen bazičnih kationov in ima posledično tudi nižji $\mathrm{pH}$, zato med $\mathrm{B}_{\mathrm{t}}$ in $\mathrm{E}$ ni večjih sprememb v pH vrednosti (Slika 6). 


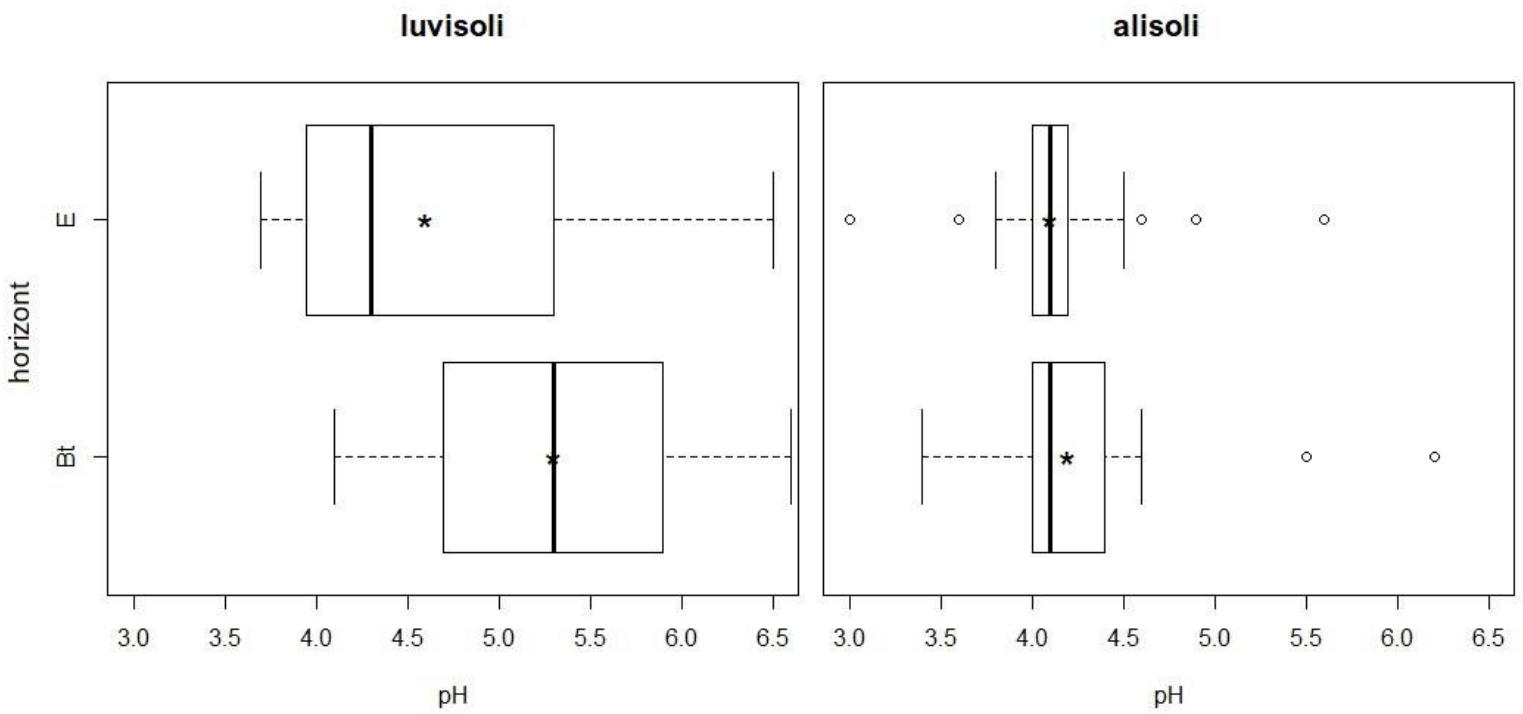

Slika 6: Okvir z ročaji (odebeljena črta $=$ mediana; okvir $=$ kvartil $25 \%, 75 \%$; sp. in zg. ročaj $=$ min, $\max ; \mathrm{krožec}=$ osamelec) za pH vrednost $\mathrm{v} \mathrm{E}$ in $\mathrm{B}_{\mathrm{t}}$ horizontih pri luvisolih in alisolih, * - povprečna vrednost; luvisoli ( $\mathrm{n}=22$ ), alisoli $(n=18)$

Figure 6: Boxplots (black thickened line = median; rectangles = quartiles $25 \%, 75 \%$; ranges = min, max; circles = outliers) of $\mathrm{pH}$ values in $\mathrm{E}$ and $\mathrm{B}_{\mathrm{t}}$ horizon in Luvisols and Alisols, sign * present average values; Luvisols ( $\mathrm{n}=22$ ), Alisols $(\mathrm{n}=18)$

Med izmenljivimi bazičnimi kationi je $\mathrm{v}$ tleh največ $\mathrm{Ca}^{2+}$ (od 0,1 do $\left.62,3 \mathrm{mmol}_{\mathrm{c}} / 100 \mathrm{~g}\right)$, sledijo $\mathrm{Mg}^{2+}(\mathrm{od}$ 0,06 do $\left.9,2 \mathrm{mmol}_{\mathrm{c}} / 100 \mathrm{~g}\right), \mathrm{K}^{+}\left(\mathrm{od} 0,04\right.$ do $62,3 \mathrm{mmol}_{\mathrm{c}}$ $/ 100 \mathrm{~g}$ ) in $\mathrm{Na}^{+}$(od 0,01 do $0,57 \mathrm{mmol}_{\mathrm{c}} / 100 \mathrm{~g}$ ) (Preglednica 6). Njihova razporeditev po profilu je za vse bazične katione podobna in značilna za izprana tla (Preglednica 6). Največ bazičnih kationov na sorptivnem delu tal je $\mathrm{v}$ organskih in humusno akumulativnih horizontih, bogatih $\mathrm{z}$ organsko snovjo (Ćirić, 1984), kot posledica biološkega kroženja (premeščanja) in $\mathrm{v}$ BC horizontih, zaradi vpliva karbonatne matične podlage. Izpranost bazičnih kationov se ponekod kaže že v A horizontih, najbolj izrazita je v E horizontih, kjer je delež bazičnih kationov najmanjši (mediana $=4,2 \mathrm{mmol}_{\mathrm{c}} / 100 \mathrm{~g}$ ). Zaradi akumulacije $\mathrm{V}$ nižjih plasteh se vsebnost bazičnih kationov $\mathrm{v}$ B horizontih povečajo $\left(\mathrm{B}_{\mathrm{t}}\right.$ : $10,2 \mathrm{mmol}_{\mathrm{c}}$ $/ 100 \mathrm{~g}, \mathrm{BC}: 17,1 \mathrm{mmol}_{\mathrm{c}} / 100 \mathrm{~g}$ ).

Kationska izmenjalna kapaciteta $\mathrm{v}$ izpranih tleh je $\mathrm{v}$ razponu od 7,4 do $100 \mathrm{mmol}_{\mathrm{c}} / 100 \mathrm{~g}$ (Slika 7). K sorptivni sposobnosti tal $\mathrm{V}$ največji meri prispeva organska snov, količina in vrste glinenih mineralov in kislost tal (Blume in sod., 2016). Horizonti $\mathrm{z}$ veliko organske snovi $\mathrm{O}_{h} / \mathrm{A}_{h}$ imajo največjo kationsko izmenjalno kapaciteto. Izprani horizonti imajo zaradi najmanjšega deleža gline najmanjšo kationsko izmenjalno kapaciteto, $\mathrm{k}$ temu lahko prispeva tudi nizek $\mathrm{pH}$, ki zmanjšuje količino negativnega naboja železovih in aluminijevih hidroksidov (Weil and Brady, 2017). V iluvialnih horizontih $B_{t}$ se kationska izmenjalna kapaciteta zopet poveča, kar razlagamo s povečanjem vsebnosti glinene frakcije in/ali $\mathrm{z}$ dvigom $\mathrm{pH}$ (Preglednica 6, Slika 7). Horizonti v izpranih tleh so večinoma distrični. Najmanjša povprečna nasičenost $\mathrm{z}$ bazičnimi kationi je v E horizontih $(28,1 \%)$, kar je v skladu s pričakovanji. Povprečna nasičenost $\mathrm{z}$ bazičnimi kationi (V) $\vee B_{t}$ horizontih je 44,7 \%, v BC horizontih $65 \%$. Razmeroma visoke vrednosti $\mathrm{v}$ BC horizontih pripisujemo vplivu matične podlage. Razlike so med luvisoli in alisoli; argični horizonti v luvisolih so evtrični, mediana deleža bazičnih kationov je $64,5 \%$, medtem ko so pri alisolih distrični, z vrednostjo $32,2 \%$. 
Preglednica 6: Mediane (min-max) vsebnosti izmenljivih bazičnih kationov, izmenljive kislosti in vsote bazičnih kationov po horizontih $\left(\mathrm{mmol}_{\mathrm{c}} / 100 \mathrm{~g}\right)$

Table 6: Median values (min-max) of exchangeable cations and sum of exchangeable base cations by horizons $\left(\mathrm{mmol}_{\mathrm{c}} / 100 \mathrm{~g}\right)$

\begin{tabular}{|c|c|c|c|c|c|c|}
\hline Horizont & $\begin{array}{l}\mathrm{Ca}^{2+} \\
\left(\mathrm{mmol}_{\mathrm{c}} / 100 \mathrm{~g}\right)\end{array}$ & $\begin{array}{l}\mathrm{Mg}^{2+} \\
\left(\mathrm{mmol}_{\mathrm{c}} / 100 \mathrm{~g}\right)\end{array}$ & $\begin{array}{l}\mathrm{K}^{+} \\
\left(\mathrm{mmol}_{\mathrm{c}} / 100 \mathrm{~g}\right)\end{array}$ & $\begin{array}{l}\mathrm{Na}^{+} \\
\left(\mathrm{mmol}_{\mathrm{c}} / 100 \mathrm{~g}\right)\end{array}$ & $\begin{array}{l}\mathrm{H}^{+} \\
\left(\mathrm{mmol}_{\mathrm{c}} / 100 \mathrm{~g}\right)\end{array}$ & $\begin{array}{l}\text { Vsota } \\
\text { bazičnih } \\
\text { kationov }\end{array}$ \\
\hline $\begin{array}{l}\mathrm{O}_{\mathrm{h}}+\mathrm{A}_{\mathrm{h}} \\
(\mathrm{n}=18)\end{array}$ & $14,25(0,96-62,3)$ & $1,94(0,59-7,7)$ & $0,54(0,12-0,9)$ & $0,13(0,07-0,57)$ & $28,90(12,4-41,2)$ & $\begin{array}{l}18,30 \\
(2,3-65,8)\end{array}$ \\
\hline $\begin{array}{l}A \\
(n=46)\end{array}$ & $6,16(0,20-28,1)$ & $0,88(0,06-7,4)$ & $0,16(0,04-0,6)$ & $0,07(0,01-0,33)$ & $12,93(5,7-32,7)$ & $\begin{array}{l}8,05 \\
(0,3-29,2)\end{array}$ \\
\hline $\begin{array}{l}E \\
(n=55)\end{array}$ & $3,42(0,09-20,6)$ & $0,56(0,07-6,4)$ & $0,10(0,07-6,4)$ & $0,05(0,01-0,20)$ & $12,65(3,2-33,4)$ & $\begin{array}{l}4,20 \\
(0,3-25,4)\end{array}$ \\
\hline $\begin{array}{l}\mathrm{B}_{\mathrm{t}} \\
(\mathrm{n}=74)\end{array}$ & $6,97(0,10-29,5)$ & $1,04(0,13-9,2)$ & $0,17(0,06-0,4)$ & $0,09(0,01-0,19)$ & $12,17(4,8-32,1)$ & $\begin{array}{l}10,20 \\
(0,7-30,9)\end{array}$ \\
\hline $\begin{array}{l}\mathrm{BC} \\
(\mathrm{n}=6)\end{array}$ & $15,33(4,76-33,0)$ & $2,15(0,78-3,9)$ & $0,26(0,18-0,3)$ & $0,10(0,08-0,17)$ & $9,33(5,6-11,4)$ & $\begin{array}{l}17,10 \\
(8,1-37,3)\end{array}$ \\
\hline
\end{tabular}
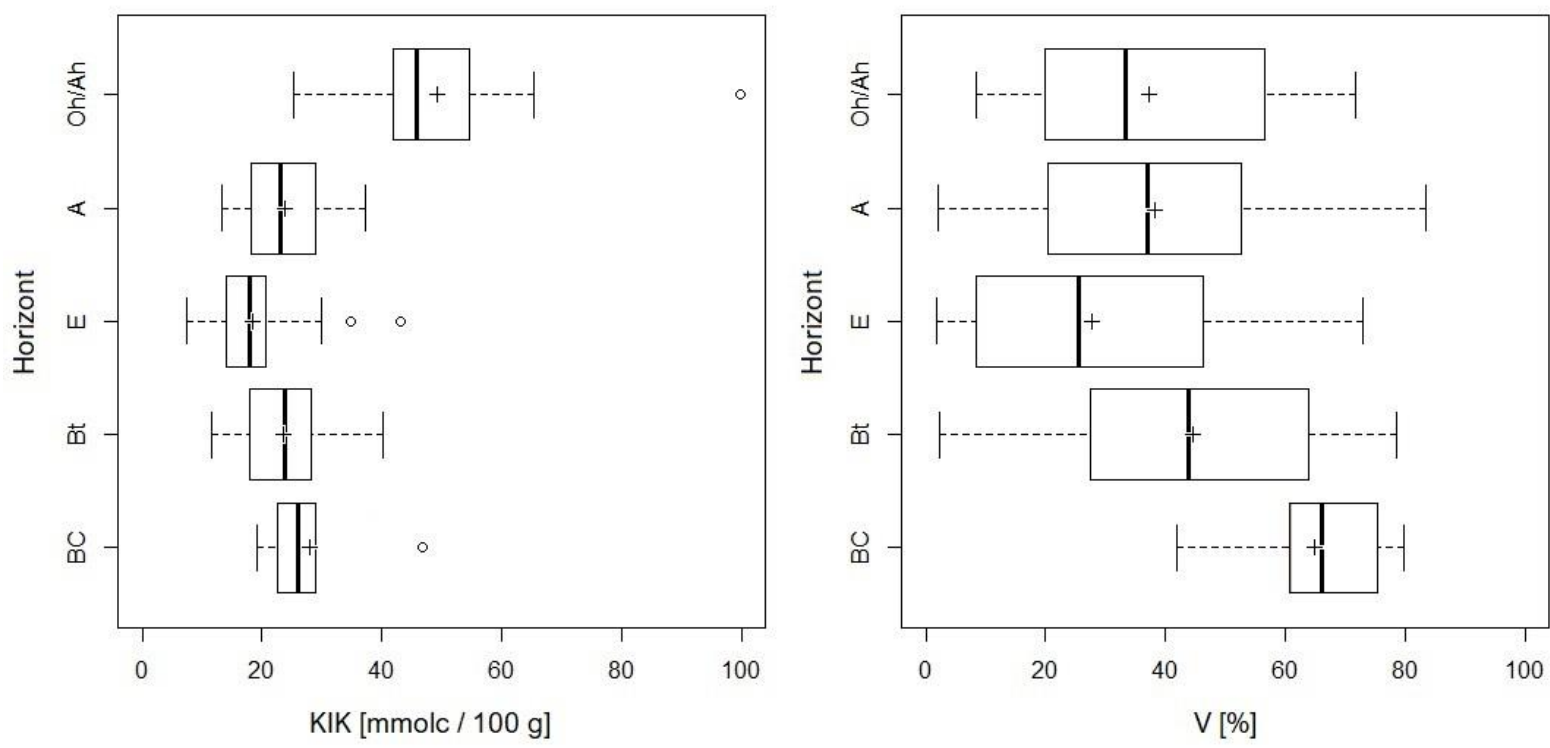

Slika 7: Okvirja z ročaji (odebeljena črta = mediana; okvir $=$ kvartil $25 \%, 75 \%$; sp. in zg. ročaj = min, max; krožec = osamelec) kationske izmenjalne kapacitete $\left(\mathrm{mmol}_{\mathrm{c}} / 100 \mathrm{~g}\right)$ (levo) ter deleža bazičnih kationov (desno) po horizontih; znak + prikazuje povprečno vrednost

Figure 7: Boxplots (black thickened line = median; rectangles = quartiles $25 \%$, $75 \%$; ranges = min, max; circles = outliers) of cation exchange capacity $\left(\mathrm{mmol}_{\mathrm{c}} / 100 \mathrm{~g}\right)$ and base saturation by horizon; sign + present average values

Gozdna raba tal omogoča bolj ali manj nemoten razvoj tal $\mathrm{v}$ smeri procesov izpiranja, medtem ko kmetijska raba $z$ oranjem, gnojenjem in apnenjem zavira in blaži posledice izpiranja. Po pričakovanjih se zato večina, 34 od 49 profilov, izpranih tal nahaja $\mathrm{v}$ gozdu. Vrhnji $\mathrm{O}_{\mathrm{h}} / \mathrm{A}_{\mathrm{h}}$ horizonti imajo povprečno $15 \%$ organskega ogljika, humusno akumulativni horizonti 3,2\%. Z globino se vsebnost organske snovi zmanjšuje. V eluvialnih in iluvialnih horizontih je običajno manj kot $1 \%$ organskega ogljika. V nekaterih iluvialnih horizontih so vrednosti organskega ogljika tudi večje, ponekod nad $2 \%$, kar je lahko posledica načina vzorčenja; v vzorec se lahko zajame rove korenin ali deževnikov, ki so bogati z organsko snovjo. Podobno razporeditev po globini kaže tudi vsebnost skupnega dušika v tleh. Največje vsebnosti so $v \mathrm{O}_{\mathrm{h}} / \mathrm{A}_{\mathrm{h}}$ horizontih (mediana $0,78 \%$ ) in $\mathrm{v}$ A horizontih (mediana 0,22 \%), najmanjše $\mathrm{v} E, \mathrm{~B}_{\mathrm{t}}$ in $\mathrm{BC}$ horizontih (mediana $<0,11 \%$ ). $\mathrm{C} / \mathrm{N}$ razmerje $\mathrm{v}$ zgornjih $\mathrm{O}_{\mathrm{h}} / \mathrm{A}_{\mathrm{h}}$ horizontih je $\mathrm{v}$ povprečju nad 20, kar je značilno za gozdna tla $\mathrm{s}$ prhninastim ali surovim humusom. $\mathrm{Z}$ globino se razmerje zmanjšuje in je $v B_{t}$ horizontih povprečno 9,4 . 
Vsebnosti rastlinam dostopnega fosforja $\left(\mathrm{P}_{2} \mathrm{O}_{5}\right)$ in kalija $\left(\mathrm{K}_{2} \mathrm{O}\right)$ so majhne, kar je značilno za gozdna tla, ki jih ne gnojimo. Podobno kot pri bazičnih kationih na sorptivnem delu tal, tudi pri izmenljivem fosforju in kaliju opazimo obogatitev $\mathrm{v}_{\mathrm{h}} \mathrm{O}_{\mathrm{h}}$ horizontih, ki je posledica biološke migracije in akumulacije. $\mathrm{Z}$ globino se vsebnost izmenljivega fosforja zmanjšuje, kar je značilno za vsa tla. Eluvialno-iluvialni procesi pri fosforju niso opazni, kar kaže, da je fosfor dobro vezan na sorptivnem delu tal, predvsem na aluminijevih oksidih in hidroksidih. Vsebnost izmenljivega kalija $\left(\mathrm{K}_{2} \mathrm{O}\right)$ je večja kot vsebnost fosforja. Izvor izmenljivega kalija $\mathrm{v}$ tleh je preperevanje primarnih silikatov in glinenih mineralov, ki s površinskim in medplastovnim negativnim nabojem predstavljajo tudi mesto vezave za kalijeve ione. Razporeditev izmenljivega kalija $\mathrm{z}$ globino potrjuje eluvialno-iluvialne procese; najmanjše vsebnosti so v izpranem E horizontu (Preglednica 7).

Preglednica 7: Podatki o organskem ogljiku (\%), dušiku (\%), C/N razmerju in izmenljivem fosforju in kaliju (mg/100 g tal) po horizontih, mediana (min-max)

Table 7: Data for $\mathrm{C}_{\text {org }}(\%)$, nitrogen $(\%), \mathrm{C} / \mathrm{N}$ ratio and readily available phosphorus and potassium $(\mathrm{mg} / 100 \mathrm{~g})$ by horizons, median (min-max)

\begin{tabular}{|c|c|c|c|c|c|}
\hline Horizon & $\begin{array}{l}\mathrm{C}_{\text {org. }} \\
(\%)\end{array}$ & $\begin{array}{l}\mathrm{N} \\
(\%)\end{array}$ & $\mathrm{C} / \mathrm{N}$ & $\begin{array}{l}\mathrm{P}_{2} \mathrm{O}_{5} * \\
(\mathrm{mg} / 100 \mathrm{~g})\end{array}$ & $\begin{array}{l}\mathrm{K}_{2} \mathrm{O} * * \\
(\mathrm{mg} / 100 \mathrm{~g})\end{array}$ \\
\hline $\begin{array}{l}\mathrm{O}_{\mathrm{h}}+\mathrm{A}_{\mathrm{h}} \\
(\mathrm{n}=17)\end{array}$ & $15,04(8,9-40,99)$ & $0,78(0,15-1,68)$ & $21,2(15,5-100,2)$ & $10,95(1,3-44,5)$ & $23,8(8,6-71,1)$ \\
\hline $\begin{array}{l}\text { A } \\
(n=44)\end{array}$ & $3,23(0,75-8,22)$ & $0,22(0,07-0,6)$ & $14,6(3,8-24,6)$ & $3,15(0,3-31,8)$ & $8,7(1,4-34,2)$ \\
\hline $\begin{array}{l}E \\
(n=46)\end{array}$ & $1,34(0,29-5,7)$ & $0,11(0,03-0,6)$ & $12,6(0,58-28,3)$ & $1,8(0,1-4)$ & $5,0(1,2-12,9)$ \\
\hline $\begin{array}{l}\mathrm{B}_{t} \\
(\mathrm{n}=48)\end{array}$ & $0,77(0,12-3,1)$ & $0,08(0,04-0,22)$ & $9,5(1,93-19,3)$ & $0,95(0,83-1,5)$ & $6,75(4,5-9,0)$ \\
\hline $\begin{array}{l}\mathrm{BC} \\
(\mathrm{n}=6)\end{array}$ & $1(0,24-2,73)$ & $0,09(0,06-0,22)$ & $9,45(3,96-16,28)$ & $0,9(0,5-1,3)$ & $10,45(10,2-11,2)$ \\
\hline
\end{tabular}

V skladu s pričakovanji obstajajo razlike med izpranimi tlemi $\mathrm{z}$ gozdno in kmetijsko rabo. $\mathrm{V}$ zgornjih $30 \mathrm{~cm}$ izpranih tal s kmetijsko rabo so vrednosti $\mathrm{pH}$ in zasičenosti z bazičnimi kationi statistično značilno večje $(\mathrm{n}=15, \mathrm{pH}=5, \mathrm{~V}=43,3 \%)$, kot pri tleh $\mathrm{v}$ gozdu $(\mathrm{n}=$ $34, \mathrm{pH}=4,3, \mathrm{~V}=25,5 \%)$. Večje vrednosti so lahko posledica gnojenja ali apnenja, $\mathrm{v}$ zgornjem delu »travniških tal« so lahko tudi posledica biološke migracije. Izprana tla $\mathrm{s}$ stališča kmetijstva veljajo za slabša tla (Stritar, 1984), kar pojasnjuje dejstvo, da večina profilov izpranih tal $\mathrm{s}$ kmetijsko rabo leži na travnikih, razen ponekod na Gorenjskem na prodnatih ledenodobnih terasah, kjer pridelujejo krompir (Vidic in sod., 2015). Kühn in sod. (2006) za izprana tla v njivski rabi poročajo o relativno visokih $\mathrm{pH}$ vrednostih $\mathrm{v}$ evtričnih $A_{p}, E$ in $B_{t}$ horizontih (mediana > 6), kar razlagajo $\mathrm{s}$ kmetijsko rabo.

\section{SKLEPI}

Izprana tla pokrivajo 2,3\% Slovenije. Najbolj pogosti matični podlagi, na katerih se pojavljajo v Sloveniji, sta apnenec in dolomit, sledijo sedimenti in konglomerat. V posameznih primerih jih najdemo na nekarbonatnih sedimentnih kamninah, na moreni in na flišnih kamninah. Večina izpranih tal se po WRB klasifikaciji uvršča med luvisole in alisole, kar je primerljivo $\mathrm{z}$ Italijo. V Evropi (Soil Atlas of Europe, 2005) se poleg luvisolov, retisolov in alisolov pojavljajo tudi akrisoli, ki pa jih pregled podatkov pedološke karte Slovenije ni potrdil, čeprav smo v dosedanjih študijah (Vidic in sod., 2015) izprana tla v Beli krajini opisovali kot akrična, na osnovi nizke $\mathrm{pH}$ vrednosti. V prihodnosti bo potrebno nameniti več pozornosti proučevanju akričnih tal ter upoštevati kriterije WRB klasifikacije glede kationske izmenjalne kapacitete. Eluvialno-iluvialni procesi se kažejo v teksturni razliki; razmerje v deležu gline med $B_{t}$ in $E$ horizontom je $v$ povprečju 1,63. Eluvialni horizonti imajo $\mathrm{v}$ primerjavi $\mathrm{z}$ iluvialnimi horizonti nižjo $\mathrm{pH}$ vrednost, svetlejšo barvo, manjšo količino bazičnih kationov ter manjšo kationsko izmenjalno kapaciteto. Pri pregledu klasifikacijskih kriterijev za izprana tla smo ugotovili, da v Slovenski klasifikaciji tal (Prus in sod., 2015) ni dovolj natančno opredeljena teksturna razlika. Za diagnosticiranje iluvialnega horizonta bi bilo smiselneje upoštevati merila, ki jih ima 
WRB klasifikacijski sistem (IUUS Working group WRB, 2015). Pri izpranih tleh na klastičnih sedimentnih kamninah lahko $\mathrm{k}$ teksturni diferenci med horizonti prispeva tudi razlika $\mathrm{v}$ granulometrijski sestavi posameznih plasti sedimentnih kamnin. V takih primerih bi procese premeščanja gline lahko nedvoumno dokazali s prisotnostjo glinenih prevlek, kar je bilo v preteklosti pri izkopu profila premalo natančno popisano. $\mathrm{V}$ prihodnjih raziskavah bi bilo potrebno več pozornosti usmeriti v mikromorfološki pregled tal.

\section{ZAHVALA}

Avtorja se zahvaljujeva pedologom in tehničnim sodelavcem vseh generacij, ki so delovali na Katedri za pedologijo in varstvo okolja Biotehniške fakultete in prispevali vzorce ter analitske podatke pedoloških profilov $\mathrm{V}$ bazo pedološke karte 1:25.000. Za konzultacije se še posebej zahvaljujeva višjemu predavatelju mag. Tomažu Prusu. Hvala tudi obema recenzentoma za kritičen pregled in koristne predloge.

\section{VIRI}

Arbeitkreis für Bodensystematik der Deutschen Bodenkundlichen Gesellschaft. (1998). Systematik der Böden und der Bodenbildenden Substrate Deutschlands. Göttingen: Deutschen Bodenkundlichen Gesellschaft.

Bašić, F. (2013). The soils of Croatia. Dordrecht: Springer. doi:10.1007/978-94-007-5815-5

Beaudette, D. E., Roudier, P., O'Geen, A.T. (2013). Algorithms for quantitative pedology: A toolkit for soil scientists. Computers \& Geosciences, 52, 258268. doi:10.1016/j.cageo.2012.10.020

Beaudette, D. E. (2015). Some ideas on summarizing soil color. R-Forge. Retrieved on https://r-forge.rproject.org/scm/viewvc.php/*checkout*/docs/sharp shootR/aggregate-soil- color.html?root=aqp

Blume, H. P., Brümmer, G. W., Fleige, H., Horn, R., Kandeler, E., Kögel-Knabner, I., Kretzschmar, R., Stahr, K., Wilke, BM. (2016). Scheffer/Schachtschabel soil science. Berlin: Springer. doi:10.1007/978-3-642-30942-7

Bockheim, J. G., Hartemink, A. E. (2013). Distribution and classification of soils with clay-enriched horizons in the USA. Geoderma, 209-210, 153160. doi:10.1016/j.geoderma.2013.06.009

Camargo, M. N., Klamt, E., Kauffman, J. H. (1986). Soil classification as used in Brazilian soil surveys. In: Annual report 1986 (pp. 7-42). Wageningen: ISRIC.

Carballas, T., Rodríguez-Rastrero, M., Artieda, O., Gumuzzio, J., Díaz-Raviña, M., Martín, Á. (2016). Soils of the temperate humid zone. In J. F. Gallardo (Ed.), The soils of Spain (pp. 49-144). Switzerland, Cham: Springer. doi:10.1007/978-3-319-20541-0_3

Costantini, E. A. C., Barbetti, R., Fantappiè, M., L'Abate, G., Lorenzetti, R., Magini, S. (2013). Pedodiversity. In E. A. C. Costantini \& C. Dazzi
(Eds.). The soils of Italy (pp. 105-178). Dordrecht: Springer. doi:10.1007/978-94-007-5642-7_6

Ćirić, M. (1984). Pedologija. Sarajevo: Svjetlost.

Digitalni model višin (DMV 100). Ljubljana: Ministrstvo za okolje in prostor, Geodetska uprava RS.

ESRI - Environmental Systems Research Institute. (2014). ArcGIS 10.2.2 for Desktop (software)

Fedoroff, N. (1997). Clay illuviation in Red Mediterranean soils. Catena, 171, 171-189. doi:10.1016/S0341-8162(96)00036-7

IUUS Working group WRB. (2015). International soil classification system for naming soils and creating legends for soil maps. World soil resources reports No. 106. Rome: FAO.

Janousek, V., Farrow, C. M., Erban, V. (2006). Interpretation of whole-rock geochemical data in igneous geochemistry: introducing Geochemical Data Toolkit (GCDkit). Journal of Petrology, 47 (6), 1255-1259. doi:10.1093/petrology/eg1013

Kobal, M. (2011). Vpliv sestojnih, talnih in mikrorastiščnih razmer na rast in razvoj jelke (Abies alba Mill.) na visokem krasu Snežnika. Doktorsko delo. Univerza v Ljubljani, Biotehniška fakulteta, Oddelek za agronomijo: $151 \mathrm{str}$.

Keys to soil taxonomy. (2014). Washington, United States Department of Agriculture, Natural Resources Conservation Service.

Kralj, T. (2008). Primerjava sistemov za razvrščanje tal na izbranih tleh $\mathrm{v}$ Sloveniji. Doktorsko delo. Univerza v Ljubljani, Biotehniška fakulteta, Oddelek za agronomijo: 151 str.

Kühn, P., Billwitz, K., Bauriegel, A., Kühn, D., Eckelmann, W. (2006). Distribution and genesis of 
Fahlerden (Albeluvisols) in Germany. Journal of plant nutrition and soil science, 169, 420-433. doi:10.1002/jpln.200521963

Lavkulich, L. M., Arocena, J. M. (2011). Luvisolic soils of Canada: Genesis, distribution, and classification. Canadian journal of soil science, 91, 781-806. doi:10.4141/cjss2011-014

Nestroy, O., Aust, G., Blum, W.E.H., Englisch, M., Hager, H., Herzberger, E., Kilian, W., Nelhiebel, P., Ortner, G., Pecina, E., Pehamberger, A., Schneider, W., Wagner, J. (2011). Systematische Gliederung der Böden Österreichs. Österreichische Bodensystematik 2000 in der revidierten Fassung von 2011. Wien: Österreichische Bodenkundliche Gesellschaft.

Prus, T., Kralj, T., Vrščaj, B., Zupan, M., Grčman, H. (2015). Slovenska klasifikacija tal. Ljubljana: UL, Biotehniška fakulteta in Kmetijski inštitut Slovenije.

Quénard, L., Samouëlian, A., Laroche, B., Cornu, S. (2011). Lessivage as a major process of soil formation: A revisitation of existing data. Geoderma, 167-168, 135-147. doi:10.1016/j.geoderma.2011.07.031

R Development Core Team. (2016). R: A language and environment for statistical computing. $\mathrm{R}$ Foundation for Statistical Computing, Vienna, Austria. Retrieved on http://www.R-project.org/

Shaetzl, R., Anderson, S. (2005). Soils - Genesis and geomorphology. Cambridge, Cambridge university press. doi:10.1017/CBO9780511815560

Soil Atlas of Europe. (2005). Luxembourg: European Soil Bureau Network, European Commission.

Soil Survey Staff. (1992). Soil survey laboratory methods manual. Ver. 2.0. USDA/NRCS, Soil Survey Investigations Report No. 42. U.S. Government. Printing Office, Washington, DC.

Stritar, A. (1972). Mesto vrištine u klasifikaciji zemljišta Jugoslavije - 2. dio. Zemljište i biljka, 21, 429-436.

Stritar, A. (1984). Pedologija: (kompendij). Ljubljana: Partizanska knjiga.
Stritar, A. (1990). Krajina, krajinski sistemi; Raba in varstvo tal $\mathrm{v}$ Sloveniji. Ljubljana: Partizanska knjiga.

Sušin, J. (1964). Doprinos k poznavanju terre rosse v Slovenskem primorju. Doktorsko delo. Univerza v Ljubljani, Biotehniška fakulteta, Oddelek za agronomijo: $106 \mathrm{p}$.

Škorič, A., Filipovski, G., Čirič, M. (1985). Klasifikacija zemljišta Jugoslavije. Sarajevo: Akademija nauka i umjetnosti Bosne i Hercegovine.

TIS/ICPVO - Infrastrukturni center za pedologijo in varstvo okolja, Biotehniška fakulteta, Univerza v Ljubljani, Ljubljana 1999-2017 (Talni informacijski system Slovenije).

Turniški, R. (2016). Pedološke, mineralne in geokemične lastnosti izpranih tal $\mathrm{v}$ Sloveniji. Magistrsko delo. Univerza v Ljubljani, Biotehniška fakulteta, Oddelek za agronomijo: $55 \mathrm{p}$.

Urbančič, M., Simončič, P., Prus, T., Kutnar, L. (2005). Atlas gozdnih tal Slovenije. Ljubljana: Gozdarski inštitut Slovenije.

Vidic, N. (1989). Geokemija tal na terasah reke Save. Magistrsko delo. Univerza v Ljubljani, Fakulteta za naravoslovje in tehnologijo, VTO Montanistika, Odsek za geologijo: $58 \mathrm{p}$.

Vidic, N. J., Lobnik, F. (1997). Rates of soil development of the chronosequence in the Ljubljana Basin, Slovenia. Geoderma, 76, 35-64. doi:10.1016/S0016-7061(96)00098-5

Vidic, N., Prus, T., Grčman, H., Zupan, M., Lisec, A., Kralj, T., Vrščaj, B., Rupreht, J., Šporar, M., Suhadolc, M., Mihelič, R., Lobnik, F. (2015). Tla Slovenije s pedološko karto v merilu 1:250.000. Luksemburg: Publications office of the European Union.

Vrščaj, B., Repe, B., Simončič, P. (2017). The soils of Slovenia. Dordrecht: Springer. doi:10.1007/978-94017-8585-3

Weil, R. R., Brady, N. C. (2017). The nature and properties of soils, $15^{\text {th }}$ edition. Harlow: Pearson Education. 